\title{
PERAN TEH HIJAU TERHADAP OVARIUM, ENDOMETRIUM DAN AORTA TIKUS YANG DIPAPAR DEPOMEDROXY PROGESTERONE ACETATE (DMPA)
}

\author{
Nora Veri* \\ *Prodi Kebidanan Langsa Poltekkes Kemenkes Aceh \\ E-mail : nora.rahman1983@gmail.com
}

\section{ABSTRACT PROTECTIVE EFFECTS OF GREEN TEA ON OVARIUM, ENDOMETRIUM AND AORTA IN RAT TREATED WITH DEPOMEDROXY PROGESTERONE ACETATE (DMPA)}

Background: The type of injectable contraceptive that is currently widely used is Depo Medroxyprogesterone Acetate (DMPA) which contains the hormone progestin, which is a synthetic material from progesterone. The use of progestin contraceptives can reduce endometrial proliferation and increase apoptosis in endometrial tissue. Cell apoptosis is triggered by an imbalance between positive signals (cell growth factors) and negative signals (DNA damage and increased levels of oxidants) under conditions of oxidative stress. Apoptosis of oocytes in large numbers will cause tissue damage which is characterized by atrophy of the ovaries and causes decreased reproductive function. Oxidative stress can be overcome with endogenous and exogenous antioxidants to reduce free radicals in the body. Green tea is one of the herbal plants that act as antioxidants and phytoestrogens, through the polyphenol compounds contained therein.

Purpose: To know the role of green tea in providing protective effects on the ovaries, endometrium and aorta in rats.

Methods: The research design used in this study was a true experiment with a post test only control group design approach. In this study, the researchers treated green tea extract at a dose of $10.8 \mathrm{mg} / \mathrm{rat} / \mathrm{day}, 21.6$ $\mathrm{mg} / \mathrm{rat} /$ day, and $43.2 \mathrm{mg} / \mathrm{rat} /$ day and exposure to DMPA at a dose of $2.7 \mathrm{mg} / \mathrm{rat} /$ day. Green tea extract was administered orally for 28 days. The research hypothesis is that green tea can increase the number of follicles, the number of endometrial glands and reduce the arteriosclerosis score of blood vessels. The preparations were stained by the Hemotoxin-Eosin (HE) method and using the OlyVIA software.

Result: There was a significant decrease in the number of corpus luteum, endometrial glands and arteriosclerosis scores due to DMPA exposure but not on the number of follicles. Green tea extract was able to increase the number of endometrial glands at a dose of $10.8 \mathrm{mg} /$ day, but there was no significant difference between doses. Green tea extract was able to reduce arteriosclerosis scores, but the most effective dose was $43.2 \mathrm{mg} / \mathrm{day}$.

Conclusion: DMPA exposure was able to significantly reduce the number of corpus luteum, the number of endometrial glands and arteriosclerosis score, but there was no significant difference in the number of primary, secondary, tertiary and de Graff follicles, there was a difference in the number of corpus luteum in the group exposed to DMPA, green tea extract was able to increase the number of endometrial glands and decrease the arteriosclerosis score.

Suugestion It is necessary to determine the phase of the reproductive cycle before calculating the number of follicles and examining the level of the hormone estrogen to determine whether the experimental animal has become a hypoestrogen model or not.

Keywords : Progesterone, Contraception, Green Tea, Antioxidant

\section{ABSTRAK}

Latar Belakang : Jenis kontrasepsi suntik yang saat ini banyak digunakan adalah Depo Medroxyprogesterone Acetate (DMPA) yang mengandung hormon progestin yaitu bahan sintestis dari progesteron. Penggunaan kontrasepsi progestin dapat menurunkan proliferasi endometrium dan meningkatkan apoptosis pada jaringan endometrium. Apoptosis sel dipicu karena adanya ketidakseimbangan antara sinyal positif (faktor pertumbuhan sel) dan sinyal negatif (kerusakan DNA dan peningkatan kadar oksidan) pada kondisi stress oksidatif. Apoptosis pada oosit dalam jumlah yang besar akan mengakibatkan kerusakan jaringan yang ditandai dengan terjadinya atrofi pada ovarium dan menyebabkan fungsi reproduksi menurun. Stress oksidatif dapat diatasi dengan antioksidan endogen dan eksogen untuk menurunkan radikal bebas dalam tubuh. Teh hijau 


\section{JKM (Jurnal Kebidanan Malahayati),Vol 7,No.3.Juli 2021, \\ ISSN (Print) 2476-8944 ISSN (Online) 2579-762X, Hal 568-575}

merupakan salah satu tanaman herbal yang berperan sebagai antioksidan dan fitoestrogen, melalui senyawa polifenol yang terkandung didalamnya.

Tujuan : Mengetahui peran teh hijau dalam meberikan efek protektif terhadap ovarium, endometrium dan aorta pada tikus.

Metode : Rancangan penelitian yang digunakan dalam penelitian ini adalah true experiment dengan pendekatan post test only control group design. Dalam penelitian ini perlakuan peneliti adalah pemberian ekstrak teh hijau dengan dosis 10,8 mg/tikus/hari, 21,6 mg/tikus/hari, dan 43,2 mg/tikus/hari dan paparan DMPA dosis 2,7 mg/tikus/hari pada tikus. Ekstrak teh Hijau diberikan secara oral selama 28 hari. Hipotesis penelitian adalah teh hijau mampu meningkatkan jumlah folikel, jumlah kelenjar endometrium dan menurunkan skor arteriosklerosis pembuluh darah. Preparat diwarnai dengan metode Hemotoxin-Eosin (HE) dan menggunakan software OlyVIA.

Hasil : Terjadi penurunan jumlah korpus luteum, kelenjar endometrium dan skor arteriosklerosis akibat paparan DMPA secara bermakna namun tidak pada jumlah folikel. Ekstrak teh hijau mampu meningkatkan jumlah kelenjar endometrium pada dosis $10.8 \mathrm{mg} / \mathrm{hari}$, namun tidak ada perbedaan yang signifikan antar dosis. Ekstrak teh hijau mampu menurunkan skor arteriosklerosis, namun yang paling efektif adalah dosis $43.2 \mathrm{mg} / \mathrm{hari}$.

Kesimpulan : Paparan DMPA mampu menurunkan jumlah korpus luteum, jumlah kelenjar endometrium dan skor arteriosklerosis secara bermakna, namun tidak ada perbedaan yang bermakna pada jumlah folikle primer, sekunder, tersier dan de Graff, ada perbedaan jumlah korpus luteum pada kelompok yang dipapar DMPA, ekstrak teh hijau mampu meningkatkan jumlah kelenjar endometrium dan menurunkan skor arteriosklerosis.

Saran Perlu menentukan fase siklus reproduksi sebelum dilakukan perhitungan jumlah folikel dan pemeriksaan kadar hormon estrogen untuk menentukan apakah hewan coba sudah menjadi model hypoestrogen atau belum.

Kata Kunci : DMPA, Kontrasepsi, Teh Hijau, Antioksidan

\section{PENDAHULUAN}

Program Keluarga Berencana di Indonesia yang diterapkan melalui metode kontrasepsi yang bertujuan untuk meningkatkan pembinaan, partisipasi dan kemandirian serta kesehatan reproduksi (Susanti, 2015). Wanita usia subur di Indonesia yang menggunakan kontrasepsi sejumlah 29.375 jiwa dan metode yang paling banyak dipilih adalah suntikan 57,12\% (Hartono, 2019). Jenis kontrasepsi suntik yang saat ini banyak digunakan adalah Depo Medroxyprogesterone Acetate (DMPA) yang mengandung hormon progestin yaitu bahan sintesis dari progesterone (Speroff \& Fritz, 2005; Walker \& Badawy, 2013). Efek samping utama dari kontrasepsi DMPA pada pemakaian enam bulan adalah gangguan menstruasi/ bleeding pattern $(93,60 \%)$, pertambahan berat badan $(48 \%)$, nyeri pada sendi $(24 \%)$, kekeringan pada vagina $(10,4 \%)$ dan kolesterolmia (Fazdria, 2020; Veisi \& Zangeneh, 2013).

Gangguan menstruasi yang terjadi meliputi menstruasi dengan waktu lama (prolonged bleeding), menstruasi yang tidak teratur (irregular bleeding), amenorea (infrequent bleeding) dan perdarahan bercak (breakthrough bleeding) (Adeyemi \& Adekanle, 2012). Banyak wanita berhenti menggunakan kontrasepsi DMPA karena gangguan menstruasi tersebut dan pada akhirnya bisa mengakibatkan kehamilan yang tidak dinginkan (Mohebbi-Kian et al., 2014). Irregular bleeding merupakan gangguan menstruasi yang paling sering terjadi pada pengguna DMPA yang dialami oleh $70 \%$ pengguna pada tahun pertama dan $10 \%$ pada tahun berikutnya (Veisi \& Zangeneh, 2013).

Gangguan menstruasi pada pengguna kontrasepsi DMPA disebabkan oleh perubahan morfologi endometrium, profil reseptor steroid endometrium, morfologi vaskular endometrium, perubahan fungsi serta mekanisme hemostasis pada endometrium, kelainan angiogenesis dan sistem repair endometrium (Pratiwi et al., 2016). Terjadi perubahan pada vaskular endometrium yang meliputi pelebaran, penipisan dan fragilitas pada dinding vaskular akibat penggunaan kontrasepsi progestin(Krikun et al., 2010).

Penggunaan kontrasepsi progestin akan menurunkan proliferasi endometrium dan meningkatkan apoptosis pada jaringan endometrium (Veri et al., 2015). Apoptosis sel dipicu karena adanya ketidakseimbangan antara sinyal positif (faktor pertumbuhan sel) dan sinyal negatif (kerusakan DNA dan peningkatan kadar oksidan) pada kondisi stress oksidatif (Agarwal et al., 2012). Apoptosis pada oosit dalam jumlah yang besar akan mengakibatkan kerusakan jaringan yang ditandai dengan terjadinya atrofi pada ovarium 
dan menyebabkan fungsi reproduksi menurun (Lord \& John Aitken, 2013).

Stres oksidatif pada pengguna DMPA juga diperantai oleh rendahnya kadar estrogen endogen yang dapat mencegah pembentukan radikal bebas (Borrás et al., 2010). DMPA bekerja pada pola hipotalamus-hipofisis-ovarium dengan menghambat Gonadotropin Realising Hormon ( $\mathrm{GRH})$ pada hipofisis sehingga tidak terjadinya ovulasi dan penurunan sirkulasi estrogen (Zalenskaya et al., 2018). $17 \beta$-estradiol merupakan salah satu golongan estrogen yang dapat meningkatkan mekanisme perlindungan antioksidan dan mencegah kematian sel dan peroksidase lipid, menstimulasi eNOS serta generasi NO berikutnya melalui reseptor estrogen dan meningkatkan kerja enzim antioksidan endogen yang mencegah kerusakan jaringan dengan menstabilkan kadar ROS (Förstermann et al., 2017). Banyaknya efek samping dari kontrasepsi suntik, ditakutkan akan membuat banyak WUS berhenti menggunakan kontrasepsi mengingat kontrasepsi suntik DMPA banyak diminati. Maka dari itu harus ditemukan suatu terapi komplementer untuk mengurangi efek dari DMPA tersebut.

Stres oksidatif dapat diatasi dengan antioksidan endogen dan eksogen untuk menurunkan radikal bebas dalam tubuh. Antioksidan eksogen yang terdapat dalam tanaman obat adalah relatif aman dan telah banyak digunakan sejak dulu (Chan et al., 2011). Teh hijau (Camelia sinensis) merupakan salah satu tanaman herbal yang berperan sebagai antioksidan dan fitoestrogen, melalui senyawa polifenol yang terkandung di dalamnya. Daun teh hijau kering mengandung polifenol yang mempunyai kemampuan bioavaibilitas yang bagus dan didistribusikan ke jaringan (Cai et al., 2018; Kim et al., 2014). Salah satu polifenol penting adalah flavonoid yang terdiri dari flavone, flavaonone, isoflavone, flavonol, flavanol dan antosianin Isoflavon atau fitoestrogen dapat berikatan dengan reseptor estrogen sebagai bagian dari aktivitas hormonal. Pada kondisi hipoestrogen, akan terdapat banyak kelebihan reseptor estrogen yang tidak terikat, walaupun afinitasnya rendah, isoflavon dapat berikatan dengan reseptor tersebut (Desmawati et al., 2018; Tsao, 2010). Teh hijau juga berfungsi sebagai antioksidan melalui peran antosianin dan senyawa flavanol golongan katekin seperti epikatekin (EC), epikatekin galat (EGC), epigalokatekin galat (EGCG) dan apigalokatekin (EGC), kafein, tanin, asam glutamat, asam aspartat, arginin, kalium dan asam amino lainnya yang terkandung di dalamnya (Ramiréz-Aristizabal et al., 2015).

Peran antioksidan dari teh hijau adalah melalui mekanisme kerjanya sebagai penangkap radikal bebas aktif sebelum radikal tersebut menyerang molekul biologis penting (Manea et al., 2014). Teh dapat meningkatkan antioksidan plasma, menurunkan peroksidase lipid, kolesterolmia dan mencegah penyakit vaskular pada manusia (Bhardwaj \& Khanna, 2013; Maydawati \& Veri, 2020). Disamping itu teh hijau juga meningkatkan sistem imun, memperbaiki fungsi organ tubuh, mengabsorpsi ion logam menurunkan stress oksidatif pada sel endotel mikrovaskular dan berfungsi sebagai anti inflamasi pada keadaan stress oksidatif (González-Gallego et al., 2010; Oz, 2017). Melalui mekanisme diatas diharapkan pemberian ekstrak teh hijau dapat mencegah dan menurunkan efek samping dari penggunaan DMPA yang dapat merugikan wanita pada masa yang akan datang.

\section{METODOLOGI PENELITIAN}

Rancangan penelitian yang digunakan dalam penelitian ini adalah true experimental dengan pendekatan post test only control group design. Dalam penelitian ini perlakuan peneliti adalah pemberian ekstrak teh hijau dengan dosis 10,8 $\mathrm{mg} /$ tikus/hari, 21,6 mg/tikus/hari, dan 43,2 $\mathrm{mg} /$ tikus/hari dan paparan DMPA dosis 2,7 $\mathrm{mg} /$ tikus/hari pada hewan coba tikus (Rattus norvegicus) (Veri et al., 2015, 2019). Respon yang terjadi akibat adanya perlakuan diamati setelah perlakuan selesai diberikan yaitu organ ovarium (yang diamati adalah jumlah corpus luteum, folikel primer, folikel sekunder, folikel tersier dan folikel de Graff) jaringan endometrium (jumlah kelenjar endometrium) dan pada aorta (skor arteriosklerosis). Penelitian ini menggunakan Rattus norvegicus galur wistar dengan metode Rancangan Acak Lengkap (RAL). Tikus dikelompokkan dalam 5 kelompok yaitu Kelompok kontrol negatif (K-) yang diinjeksi normal saline, kelompok kontrol positif $(\mathrm{K}+)$ yang diinjeksi DMPA tanpa ekstrak teh hijau, kelompok perlakuan 1 (KP1) diberi ekstrak teh hijau dosis I (10,8 mg/tikus/hari) dan DMPA 2,7 mg/tikus/hari, kelompok perlakuan 2 (KP2) diberi ekstrak teh hijau dosis II (21,6 mg/tikus/hari) dan DMPA 2,7 mg/tikus/hari serta kelompok perlakuan 3 (KP3) diberi ekstrak teh hijau dosis III (43,2 $\mathrm{mg} /$ tikus/hari) dan DMPA 2,7 mg/tikus/hari.

Ekstraksi daun teh hijau kering sebanyak 200 gram dan diproses dengan metode maserasi dengan pelarut etanol $96 \%$ di laboratorium kimia Polinema Malang. Hasil ekstraksi berupa ekstrak 


\section{JKM (Jurnal Kebidanan Malahayati),Vol 7,No.3.Juli 2021, \\ ISSN (Print) 2476-8944 ISSN (Online) 2579-762X, Hal 568-575}

kental (pasta) sebanyak 20 gram dan diberikan secara oral dengan menggunakan sonde pada tikus setiap hari selama 4 minggu. Pemberian ekstrak teh hijau yang diproses dengan metode maserasi dilakukan sesuai dengan dosis yang telah ditentukan yaitu 10,8 $\mathrm{mg} / \mathrm{tikus} / \mathrm{hari}, \quad 21,6$ $\mathrm{mg} / \mathrm{tikus} / \mathrm{hari}$ dan $43,2 \mathrm{mg} / \mathrm{tikus} / \mathrm{hari}$ (Veri et al., 2015) .

DMPA yang digunakan adalah Depoprogestin ${ }^{\circledR} 150 \mathrm{mg}$ yang diinjeksi seminggu sekali selama 4 minggu pada hewan coba dengan dosis 2,7 mg/tikus/minggu dan disuntik secara intramuskular pada paha (Wahyuni et al., 2016). Preparat Slide Histopatologi disiapkan dengan metode $\mathrm{HE}$ dan selanjutnya menggunakan mikroskop cahaya. Semua data diamati dengan menggunakan software OlyVIA.

\section{HASIL DAN PEMBAHASAN}

Hasil pengamatan jumlah folikel ovarium dengan mikroskop cahaya dan dianalisa dengan software OlyVia. Lebih lengkapnya seperti yang tergambar dibawah ini :

Tabel 1.

Jumlah Folikel Ovarium, Kelenjar Endometrium dan Skor Arteriosklerosis Akibat Paparan DMPA dan Ekstrak teh hijau

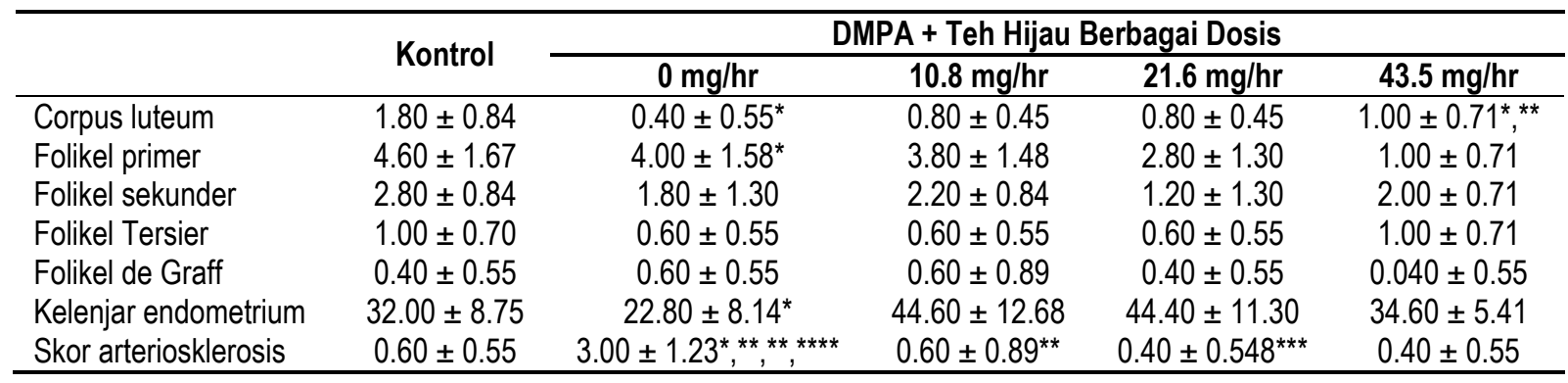

Catatan :

Nilai yang ditampilkan adalah nilai rerata \pm standar deviasi

${ }^{*} p<0.05$ jika dibandingkan dengan kelompok kontrol

${ }^{* *} p<0.05$ jika dibandingkan dengan kelompok DMPA

${ }^{* * *} p<0.05$ jika dibandingkan dengan kelompok perlakuan $1(10.8 \mathrm{mg} / \mathrm{hr})$

${ }^{* * * *} p<0.05$ jika dibandingkan dengan kelompok perlakuan $2(21.6 \mathrm{mg} / \mathrm{hr})$

${ }^{* * *} p<0.05$ jika dibandingkan dengan kelompok perlakuan $3(43.2 \mathrm{mg} / \mathrm{hr})$

Hasil penelitian ini menunjukkan terdapat perbedaan yang bermakna penurunan jumlah korpus luteum antara kelompok yang tidak dipapar DMPA dengan kelompok yang dipapar yang tampak pada rerata nilai mean dari 1.80 turun menjadi 0.40 . Selanjutnya tampak perbedaan jumlah korpus luteum pada kelompok yang diberikan ekstrak teh hijau dosis $10.8 \mathrm{mg} / \mathrm{hari}$, dosis $21.6 \mathrm{mg} / \mathrm{hari}$ dan dosis $43.5 \mathrm{mg} / \mathrm{hari}$ dibandingkan dengan kelompok tanpa ekstrak teh hijau. Namun perbedaan jumlah korpus luteum antar berbagai dosis ekstrak teh hijau tidak tampak perbedaan yang signifikan. Artinya semua dosis mampu meningkatkan jumlah korpus luteum secara bermakna. Pada tabel juga menunjukkan tampak terjadi penurunan rerata jumlah folikel primer, folikel sekunder, folikel tersier akibat paparan DMPA, namun yang signifikan penurunan terjadi pada folikel primer. Jumlah folikel sekunder pada kelompok pemberian ekstrak teh hijau juga tampak lebih kecil jika dibandingkan dengan kelompok tanpa ekstrak teh hijau. Namun paparan DMPA tidak berpengaruh terhadap jumlah folikel de Graff. Selanjutnya pemberian ekstrak teh hijau tidak berpengaruh terhadap peningkatan jumlah folikel primer, folikel tersier dan folikel de Graff. Hanya folikel sekunder yang mengalami peningkatan tamun tidak bermakna.

Tabel diatas juga menjelaskan tampak perbedaan jumlah kelenjar endometrium setelah paparan DMPA yang mengalami penurunan. Selanjutnya pemberian ekstrak teh hijau dosis 10.8 $\mathrm{mg} / \mathrm{hari}$ mampu meningkatkan jumlah kelenjar endometrium, namun tidak ada perbedaan yang signifikan antar dosis ekstrak teh hijau.

Tampak terjadi peningkatan skor arteriosklerosis pada kelompok yang tidak dipapar dengan yang dipapar DMPA. Pada kelompok yang dipapar DMPA terjadi peningkatan skor arteriosklerosis secara bermakna. Selanjutnya pemberian ekstrak teh hijau mampu menurunkan skor arteriosklerosis baik dosis $10.8 \mathrm{mg} / \mathrm{hari}$, dosis $21.6 \mathrm{mg} / \mathrm{hari}$ dan dosis $43.5 \mathrm{mg} / \mathrm{hari}$ namun 
penurunan yang signifikan terjadi pada dosis 21.6 $\mathrm{mg} / \mathrm{hari}$ dan dosis $43.5 \mathrm{mg} / \mathrm{hari}$.

\section{PEMBAHASAN}

Hasil penelitian ini menyatakan bahwa paparan DMPA menyebabkan penurunan korpus luteum di ovarium tikus. Selanjutnya pemberian ekstrak teh hijau mampu meningkatkan jumlah korpus luteum secara bermakna pada dosis 43.5 $\mathrm{mg} /$ hari. Korpus luteum dipengaruhi oleh siklus menstruasi. Korpus luteum adalah massa kuning yang terbentuk dari folikel yang mengalami ovulasi di ovarium (Stouffer \& Hennebold, 2015). Menurut penelitian terdapat hubungan antara siklus menstruasi dengan penggunaan DMPA (Andriani \& Hartinah, 2018). Penggunaan DMPA akan mengakibatkan gangguan siklus menstruasi seperti amenorea, menorragia dan spotting (Setyorini \& Lieskusumastuti, 2020).

Hasil penelitian ini juga menyimpulkan bahwa paparan DMPA juga mengakibatkan penurunan jumlah folikel primer di ovarium secara bermakna namun tidak berpengaruh terhadap jumlah folikel sekunder, tersier dan folikel de Graff. Paparan DMPA akan meningkatkan hormon progesterone dalam tubuh dan menghambat sekresi GnRH dan FSH dan pada akhirnya mengakibatkan stres oksidatif di ovarium (Ismiyati et al., 2016). Hormon estrogen mempengaruhi perkembangan folikel di ovarium. Hormon LH dan FSH yang mengatur pertumbuhan dan pematangan folikel ovarium. Sekresi estrogen oleh ovarium memicu pelepasan LH untuk ovulasi pada masa estrus. LH merangsang pembentukan korpus luteum. Penggunaan kontrasepsi progesteron jangka panjang dapat merubah struktur vaskular endometrium dan morfologi jaringan, seiring dengan terjadinya stres oksidatif dan apoptosis karena kekurangan hormon estrogen endogen. Stres oksidatif ditunjukkan dengan peningkatan kerusakan DNA (7,8-dihydro-8-oxoguanine/8-oxoG) pada kelompok yang dipapar kontrasepsi progesterone. Stres oksidatif dan juga kekurangan hormon ovarium akan menyebabkan terhambatnya pertumbuhan folikel di ovarium (Agarwal et al., 2012; Dinh et al., 2015; Tomac et al., 2011).

Hasil penelitian ini juga menyatakan bahwa terdapat perbedaan yang bermakna jumlah kelenjar endometrium setelah paparan DMPA. Mekanisme kerja DMPA adalah merubah struktur endometrium dan pada pemakaian jangka panjang akan menyebabkan atrofi endometrium. Hal ini sesuai dengan hasil penelitian bahwa terjadi peningkatan apoptosis pada stroma endometrium secara signifikan pada hari ke 14 setelah diberi DMPA 150 mg, sedangkan apoptosis pada kelenjar tidak mengalami perubahan yang signifikan. Kerusakan endometrium berhubungan dengan apoptosis yang terjadi pada jaringan tersebut dan pada akhirnya menyebabkan atrofi endometrium (Jain et al., 2006).

Pemberian polifenol teh hijau mampu menurunkan peroksidasi lipid dan apoptosis pada liver. Polifenol teh hijau berperan sebagai penangkap radikal bebas, yang bisa menurunkan jumlah radikal bebas dan memutus rantai pembentukan peroksidasi lipid pada tahap insiasi dan propagasi (El-Beshbishy, 2005). Polifenol teh hijau mampu menurunkan peroksidasi lipid secara signifikan pada tikus yang dipapar dengan AZA (Azathioprine). Polifenol teh hijau mencegah hilangnya permeabilitas membran dan menurunkan kadar radikal hidroksil endogen dengan mencegah kerusakan oksidatif akibat peroksidasi lipid dan oksidasi protein. Teh hijau mampu menghambat apoptosis sel endometrium yang diakibatkan karena stress oksidatiif akibat paparan DMPA melalui mekanisme anti apoptosis serta antioksidan dengan meningkatkan aktivitas enzim Superoxide Dismutase (SOD) (Veri et al., 2015).

Teh hijau mampu menurunkan indeks apoptosis karena katekin teh hijau mempunyai kemampuan bioavaibilitas yang tinggi, sehingga mampu bekerja di jaringan endometrium. Disamping itu teh hijau mampu mencegah stress oksidatif yang dapat menyebabkan peningkatan apoptosis melalui perannya sebagai antioksidan. Kandungan teh hijau yang sebagian besar terdiri dari katekin, asam fenolik, tanin, dan lain-lain dapat bekerja secara sinergis bersama-sama mampu memberikan efek antioksidan yang optimal dibandingkan vitamin $\mathrm{C}$ dan vitamin E. Melalui mekanisme diatas, teh hijau diduga mampu mencegah stress oksidatif pada endometrium dan mencegah terjadinya apoptosis yang berlebihan akibat penggunaan DMPA yang dapat mengakibatkan endometrium menjadi atrofi.

Hasil penelitian ini menyatakan bahwa ekstrak teh hijau dosis $10.8 \mathrm{mg} / \mathrm{hari}$ mampu menurunkan resiko arteriosklerosis akibat penggunaan DMPA. Arteriosklerosis akibat DMPA disebabkan karena kerusakan endotel jangka panjang akibat hipoestrogen pada pengguna DMPA. Hasil penelitian menyatakan bahwa teh hijau mampu melindungi vaskular dengan menjaga fungsi dan jumlah sel endotel pembuluh darah dari kerusakan (Veri et al., 2019). Hasil penelitian membuktikan penggunaan DMPA meningkatkan terjadinya disfungsi endotel yang ditandai dengan menurunkan FMD (Flow-Mediated Dilation) pada 
arteri brachialis. Penurunan FMD yang diukur dengan cardiovascular magnetic resonance pada pengguna DMPA akan memberikan efek yang merugikan pada fungsi arteri (Lizarelli et al., 2009). Estrogen berperan dalam meningkatkan aktivitas dan ekspresi endothelial Nitric Oxide Synthesis (eNOS) melalui jalur phosphatidylinotosol 3-kinase (PI3K)-Akt cascade, sehingga mengakibatkan dilatasi pembuluh darah (Park et al., 2010). Pemberian DMPA akan menurunkan produksi estrogen dan penurunan regulasi aktivitas eNOS pada sitoplasma dan inti sel endometrium (Veri et al., 2015). Kekurangan eNOS dan peningkatan apoptosis akan memicu kerusakan arteri endometrium akibat paparan DMPA (Emilda et al., 2017).

\section{SIMPULAN}

Paparan DMPA mengakibatkan penurunan jumlah korpus luteum, jumlah kelenjar endometrium dan skor arteriosklerosis secara bermakna, namun tidak ada perbedaan yang bermakna pada jumlah folikel primer, sekunder, tersier dan de Graff. Teh hijau mampu meningkatkan jumlah kelenjar endometrium dan menurunkan skor arteriosklerosis. Perlu menentukan fase siklus reproduksi sebelum dilakukan perhitungan jumlah folikel dan pemeriksaan kadar hormon estrogen untuk menentukan apakah hewan coba sudah menjadi model hypoestrogen atau belum.

\section{SARAN}

Perlu menentukan fase siklus reproduksi sebelum dilakukan perhitungan jumlah folikel dan pemeriksaan kadar hormon estrogen untuk menentukan apakah hewan coba sudah menjadi model hypoestrogen atau belum.

\section{DAFTAR PUSTAKA}

Adeyemi, A. S., \& Adekanle, D. A. (2012). Progestogen-only injectable contraceptive: Experience of women in Osogbo, southwestern Nigeria. Annals of African Medicine. https://doi.org/10.4103/15963519.91013

Agarwal, A., Aponte-Mellado, A., Premkumar, B. J., Shaman, A., \& Gupta, S. (2012). The effects of oxidative stress on female reproduction: A review. In Reproductive Biology and Endocrinology. https://doi.org/10.1186/14777827-10-49

Andriani, D., \& Hartinah, D. (2018). Hubungan Periode Penggunaan Alat Kontrasepsi Suntik 3 Bulan dengan Siklus Menstruasi. Jurnal IImu Keperawatan Dan Kebidanan. https://doi.org/10.26751/jkk.v9i2.439

Bhardwaj, P., \& Khanna, D. (2013). Green tea catechins: Defensive role in cardiovascular disorders. Chinese Journal of Natural Medicines. https://doi.org/10.1016/S18755364(13)60051-5

Borrás, C., Gambini, J., López-Grueso, R., Pallardó, F. V., \& Viña, J. (2010). Direct antioxidant and protective effect of estradiol on isolated mitochondria. Biochimica et Biophysica Acta - Molecular Basis of Disease. https://doi.org/10.1016/j.bbadis.2009.09.007

Cai, Z. Y., Li, X. M., Liang, J. P., Xiang, L. P., Wang, K. R., Shi, Y. L., Yang, R., Shi, M., Ye, J. H., Lu, J. L., Zheng, X. Q., \& Liang, Y. R. (2018). Bioavailability of tea catechins and its improvement. In Molecules. https://doi.org/10.3390/molecules23092346

Chan, E. W. C., Soh, E. Y., Tie, P. P., \& Law, Y. P. (2011). Antioxidant and antibacterial properties of green, black, and herbal teas of Camellia sinensis. Pharmacognosy Research. https://doi.org/10.4103/09748490.89748

Desmawati, Sulastri, D., Yusrawati, \& Jamsari. (2018). Phytoestrogen Intake Correlate with Blood Pressure in Minangkabau Premenopausal People. Advanced Science Letters. https://doi.org/10.1166/asl.2018.12687

Dinh, A., Sriprasert, I., Williams, A. R., \& Archer, D. F. (2015). A review of the endometrial histologic effects of progestins and progesterone receptor modulators in reproductive age women. In Contraception. https://doi.org/10.1016/j.contraception.2015. 01.008

El-Beshbishy, H. A. (2005). Hepatoprotective effect of green tea (Camellia sinensis) extract against tamoxifen-induced liver injury in rats. Journal of Biochemistry and Molecular Biology. https://doi.org/10.5483/bmbrep.2005.38.5.56 3

Emilda, A. S., Veri, N., \& Alchalidi, A. (2017). High dose of green tea infusion normalized spiral artery density in rats treated with the depotmedroxyprogesterone acetate. Journal of Intercultural Ethnopharmacology. https://doi.org/10.5455/jice.20160928012442

Fazdria, F. (2020). Teh Hijau Menurunkan Kadar Koleterol Total Pada lbu Akseptor KB Depomedroxyprogesterone Acetate (DMPA). Jurnal Kebidanan Malahayati, 6(4), 531-536. https://doi.org/10.33024/jkm.v6i4.3028 
Förstermann, U., Xia, N., \& Li, H. (2017). Roles of vascular oxidative stress and nitric oxide in the pathogenesis of atherosclerosis. In Circulation Research. https://doi.org/10.1161/Circresaha.116.3093 26

González-Gallego, J., García-Mediavilla, M. V., Sánchez-Campos, S., \& Tuñó, M. J. (2010). Fruit polyphenols, immunity and inflammation. In British Journal of Nutrition. https://doi.org/10.1017/S0007114510003910

Hartono, R. K. (2019). Determinan Pemilihan KB Pada Wanita Usia Reproduksi di Indonesia (Analisis Data SUSENAS 2012). Journal of Nursing and Health. https://doi.org/10.25099/jnh.vol1.iss1.13

Ismiyati, A., Wiyasa, I. W. A., \& Hidayati, D. Y. N. (2016). Protective Effect of Vitamins $C$ and $E$ on Depot-Medroxyprogesterone AcetateInduced Ovarian Oxidative Stress In Vivo. Journal of Toxicology. https://doi.org/10.1155/2016/3134105

Jain, J. K., Li, A., Yang, W., Minoo, P., \& Felix, J. C. (2006). Effects of mifepristone on proliferation and apoptosis of human endometrium in new users of medroxyprogesterone acetate. Human Reproduction.

https://doi.org/10.1093/humrep/dei383

Kim, H. S., Quon, M. J., \& Kim, J. a. (2014). New insights into the mechanisms of polyphenols beyond antioxidant properties; lessons from the green tea polyphenol, epigallocatechin 3gallate. In Redox Biology. https://doi.org/10.1016/j.redox.2013.12.022

Krikun, G., Buhimschi, I. A., Hickey, M., Schatz, F., Buchwalder, L., \& Lockwood, C. J. (2010). Long-term progestin contraceptives (LTPOC) induce aberrant angiogenesis, oxidative stress and apoptosis in the guinea pig uterus: A model for abnormal uterine bleeding in humans. Journal of Angiogenesis Research. $\quad$ https://doi.org/10.1186/20402384-2-8

Lizarelli, P. M., Martins, W. P., Vieira, C. S., Soares, G. M., Franceschini, S. A., Ferriani, R. A., \& Patta, M. C. (2009). Both a combined oral contraceptive and depot medroxyprogesterone acetate impair endothelial function in young women. Contraception.

https://doi.org/10.1016/j.contraception.2008. 07.024

Lord, T., \& John Aitken, R. (2013). Oxidative stress and ageing of the post-ovulatory oocyte. In
Reproduction. https://doi.org/10.1530/REP13-0111

Manea, A. M., Vasile, B. S., \& Meghea, A. (2014). Antioxidant and antimicrobial activities of green tea extract loaded into nanostructured lipid carriers. Comptes Rendus Chimie. https://doi.org/10.1016/j.crci.2013.07.015

Maydawati, V., \& Veri, N. (2020). Potensi Teh Hijau Dalam Menurunkan Kadar Kolesterol Pada Akseptor Kontrasepsi Progestin Hiperkolesterolemia. Journal of Healthcare Technology and Medicine, 6(2), 1031. https://doi.org/10.33143/jhtm.v6i2.1089

Mohebbi-Kian, E., Mohammad-AlizadehCharandabi, S., \& Bekhradi, R. (2014). Efficacy of fennel and combined oral contraceptive on depot medroxyprogesterone acetate-induced amenorrhea: A randomized placebocontrolled trial. Contraception. https://doi.org/10.1016/j.contraception.2014. 05.001

Oz, H. S. (2017). Chronic inflammatory diseases and green tea polyphenols. In Nutrients. https://doi.org/10.3390/nu9060561

Park, B., Hoffman, A., Yang, Y., Yan, J., Tie, G., Bagshahi, H., Nowicki, P. T., \& Messina, L. M. (2010). Endothelial nitric oxide synthase affects both early and late collateral arterial adaptation and blood flow recovery after induction of hind limb ischemia in mice. Journal of Vascular Surgery. https://doi.org/10.1016/j.jvs.2009.08.045

Pratiwi, R., Amran, R., Said, U., \& Saleh, I. (2016). Serum Vascular Endothelial Growth Factor (VEGF) in DMPA Acceptors: Influence on Bleeding Occurrence. Indonesian Journal of Obstetrics and Gynecology. https://doi.org/10.32771/inajog.v3i1.22

Ramiréz-Aristizabal, L. S., Ortiz, A., \& OspinaOcampo, L. F. (2015). Evaluation of the antioxidant capacity and characterization of phenolic compounds obtained from tea (Camellia sinensis) for products of different brands sold in Colombia. Pharmacologyonline.

Setyorini, C., \& Lieskusumastuti, A. D. (2020). Lama Penggunaan KB Suntik 3 Bulan Dengan Kejadian Spotting Dan Amenorrhea Di PMB Darmiati Ngemplak Boyolali. Jurnal Kebidanan Indonesia: Journal of Indonesia Midwifery. https://doi.org/10.36419/jkebin.v11i1.333

Speroff, L., \& Fritz, M. (2005). Menopause and the Perimenopausal Transition. In Clinical 


\section{JKM (Jurnal Kebidanan Malahayati),Vol 7,No.3.Juli 2021, \\ ISSN (Print) 2476-8944 ISSN (Online) 2579-762X, Hal 568-575}

gynecologic endocrinology and infertility.

Stouffer, R. L., \& Hennebold, J. D. (2015). Structure, Function, and Regulation of the Corpus Luteum. In Knobil and Neill's Physiology of Reproduction: Two-Volume Set. $\quad$ https://doi.org/10.1016/B978-0-12397175-3.00023-5

Susanti, H. A. (2015). Strategi Komunikasi Badan Kependudukan dan Keluarga Berencana Nasional (BKKBN). Jurnal ASPIKOM. https://doi.org/10.24329/aspikom.v2i4.75

Tomac, J., Cekinovć, D., \& Arapović, J. (2011). Biology of the corpus luteum. In Periodicum Biologorum.

Tsao, R. (2010). Chemistry and biochemistry of dietary polyphenols. In Nutrients. https://doi.org/10.3390/nu2121231

Veisi, F., \& Zangeneh, M. (2013). Comparison of Two Different Injectable Contraceptive Methods: Depo-medroxy Progesterone Acetate (DMPA) and Cyclofem. Journal of Family \& Reproductive Health.

Veri, N., AS, E., Mutiah, C., Seriana, I., \& Malinda, R. (2019). Protective effect of green tea on tunica adventitia and endothelial changes resulting from depot medroxy progesterone acetate. Journal of Taibah University Medical Sciences.

https://doi.org/10.1016/j.jumed.2018.10.002
Veri, N., Aulia, F., Ratnawati, R., Hidayati, D. Y. N., Noorhamdani, N., \& Dwijayasa, P. M. (2015). Protective effect of green tea against ovarian and endometrial apoptoses in rats treated with depot medroxyprogesterone acetate. Biomarkers and Genomic Medicine. https://doi.org/10.1016/j.bgm.2015.04.002

Wahyuni, E. S., Wiyasa, I. W. A., \& Nurdiana, N. (2016). Combined high dose vitamin $\mathrm{C}$ and $\mathrm{E}$ increases oxidative stress and visceral fat mass in rats treated by depotmedroxyprogesterone acetate. Middle East Fertility Society Journal. https://doi.org/10.1016/j.mefs.2016.06.001

Walker, C., \& Badawy, S. Z. A. (2013). Vaginal Atrophy following Long-Term Depot Medroxyprogesterone Acetate Use: A Case Report. Case Reports in Obstetrics and Gynecology. https://doi.org/10.1155/2013/835316

Zalenskaya, I. A., Chandra, N., Yousefieh, N., Fang, X., Adedipe, O. E., Jackson, S. S., Anderson, S. M., Mauck, C. K., Schwartz, J. L., Thurman, A. R., \& Doncel, G. F. (2018). Use of contraceptive depot medroxyprogesterone acetate is associated with impaired cervicovaginal mucosal integrity. Journal of Clinical Investigation. https://doi.org/10.1172/JCl120583 